\title{
Linear Thermal Expansion of Artificial Graphites to $1,370^{\circ} \mathrm{C}^{1}$
}

\author{
Milton D. Burdick, Benson Zweig, and R. Eugene Moreland
}

\begin{abstract}
In connection with creep studies of graphite, the need arose for accurate thermal expansion data on the three grades of graphite being investigated. Therefore, the linear thermal expansion of specimens of the three grades, cut in three directions with respect to the direction of extrusion or of molding pressure, was determined at various temperatures between $20^{\circ}$ and $1,370^{\circ} \mathrm{C}$ in vacuum. Results show that specimens cut perpendicular to the extrusion direction or parallel to the direction of molding pressure had greater expansions than specimens cut parallel to the extrusion direction or perpendicular to the molding pressure. The data obtained are tabulated.
\end{abstract}

\section{Introduction}

In connection with creep studies of graphite, the need arose for accurate thermal expansion data within the range from $980^{\circ}$ to $1,370^{\circ} \mathrm{C}$ on the particular graphites being studied. The data were needed primarily to correct for the thermal expansion that would result from changing the test temperature during elongation or creep tests of graphite in tension.

Because of the marked anisotropy of the graphite crystal, ${ }^{2}{ }^{345}$ any departure from a random orientation, as may result from the forming process, would be expected to have an effect on the thermal expansion in various directions with respect to the direction of forming. Specimens for creep testing were cut both perpendicular and parallel to the direction of extrusion or of molding pressure. Therefore, specimens for thermal expansion determinations were cut similarly to duplicate the crystal orientation of the creep specimens.

In order that the thermal expansion data might be of more general use, expansion values were obtained while heating from room temperature to $1,370^{\circ} \mathrm{C}$, and contraction values were obtained during cooling from the maximum temperature to $400^{\circ} \mathrm{C}$.

\section{Materials}

Three grades of artificial graphite were obtained in the form of blocks. For each grade, at least two specimens were made representing each of three orientations with respect to the direction of molding pressure or of extrusion. Additional specimens were used to check the reproducibility of the testing equipment and the uniformity of the block samples.

\footnotetext{
1 This project was sponsored by the NEPA division of the Fairchild Engine and A irplane Corp.

2 J. B. Nelson and D. P. Riley, The thermal expansion of graphites from $15^{\circ} \mathrm{C}$ to $800^{\circ} \mathrm{C}$ : Part I experimental; D. P. Riley, The thermal expansion of graphite: Part II, theoretical, Proc. Phys. Soc. London 57, 477 (1945)

3 Jacques Pierry, Physique etude sur la dilattaion du graphite Comp. Rend. L'A cademie Des Sciences, Paris 223, 501 (1946).

4 Peter Hidnert, Thermal expansion of artificial graphite and carbon, J. Research NBS 13, 37 (1934) RP693.

5 Peter Hidnert and W. T. Sweeney, Thermal expansion of graphite, BS Tech. Pap. 335 (1927).
}

The specimens were right cylinders machined to approximately $3 / 8$ in. in diameter by 2 in. in length. Figure 1 shows how the specimens were cut from the blocks. The cross-sectional area of the blocks perpendicular to the direction of extrusion or of molding pressure represents the die opening for the extruded Grades A and B and the mold size for Grade C.

\section{Apparatus and Methods of Test}

The dilatometer used in determining the thermal expansion of graphite was similar to that used in an investigation of zirconia. ${ }^{6}$ The dilatometer consisted of an alumina base into which three artificial sapphire rods were cemented to support the dial gage and a fourth sapphire rod centrally located to provide the mechanical linkage between the dial gage and the eylindrical graphite specimen, which rested on the alumina base. Dial gages reading either to $0.0001 \mathrm{in}$. or to $0.01 \mathrm{~mm}$ were used. Gage readings were corrected for the expansion of the sapphire. The values for the expansion of the sapphire were taken from a determination from room temperature to $1,000^{\circ} \mathrm{C}$ by the interferometer method and extrapolated to $1,400^{\circ} \mathrm{C}$ (see footnote 6). The specimen and the lower part of the dilatometer were heated in a wire-wound furnace, the inner winding of which consisted of platinum-20 percent rhodium and the outer winding of Chromel A. The furnace and the dilatometer fitted under the bell jar of a vacuum coating unit. ${ }^{7}$ The shield clamped to the tripod below the dial gage never reached a temperature above $70^{\circ} \mathrm{C}$ during a test. The equipment is shown in figure 2 .

The measurement of the temperature offered greater difficulty experimentally than did determinations of the change in length. The temperature near the specimen in the first 22 tests was measured with a

\footnotetext{
${ }^{6}$ R. F. Geller and P. J. Yavorsky, Effects of some oxide additions on the thermal length changes of zirconia, J. Research NBS 35, 87 (1945) RP1662.

7 Manufactured by Distiliation Products Inc., Rochester, N. Y. Type LC1$500-3$.
} 

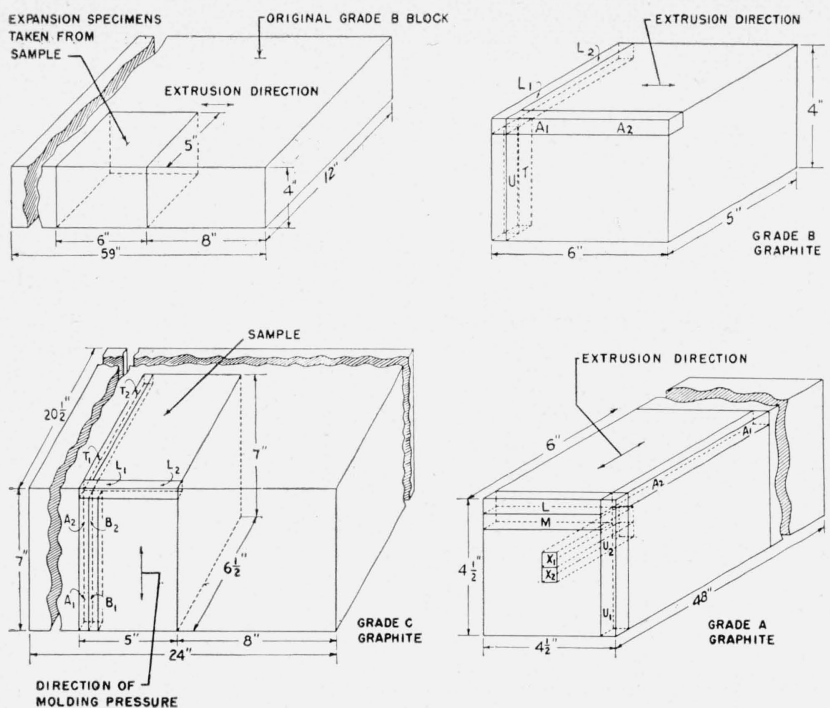

FiguRE 1. Orientation of thermal expansion specimens in sample blocks and sizes of original blocks of graphite.

30 gage $\mathrm{Pt}-\mathrm{Pt}$ 10-percent $\mathrm{Rh}$ thermocouple in a closed-end protection tube extending radially through the furnace to the specimen. The protection tube was needed to prevent reaction between the graphite and the thermocouple metal. This reaction, the nature of which was not determined, had been observed in tests at temperatures above $980^{\circ} \mathrm{C}$. In later tests, it was found that chromel-alumel thermocouples could be used without a protection tube. Although a new base-metal couple was used in each test, those removed were bright and could probably have been reused since subsequent calibration disclosed no deleterious effect.

Before making a test, the bell jar was evacuated to less than $0.05 \mathrm{~mm}$ of mercury by mechanical pumps. At the beginning of the test the oil diffusion pump was started. The vacuum attained by the combination of mechanical and oil diffusion pumps was usually less than $2 \times 10^{-4} \mathrm{~mm}$ of mercury during the test. The heating rate was then adjusted to $3^{\circ} \mathrm{C}$ per minute, and measurements of expansion were obtained at $30^{\circ} \mathrm{C}$ intervals by observing dial readings through the glass wall of the bell jar. The maximum temperature of $1,370^{\circ} \mathrm{C}$ was held for 45 min after which the specimen was cooled to $400^{\circ} \mathrm{C}$ at the same rate of $3^{\circ} \mathrm{C}$ per minute. Air was admitted when the specimen had cooled to $400^{\circ} \mathrm{C}$ to permit reaching room temperature by the next morning.

For tests 1 through 22, for which a closed-end protection tube was used, the thermocouple had to be calibrated at the prescribed rate of heating to obtain true temperature readings. It was found that, because the protection tube could not be placed in the same position for each test, an error resulted in the temperature readings especially at the beginning of the tests. The effect of this error was reduced by averaging of the values.

The average deviation between expansion values determined under similar conditions for the same

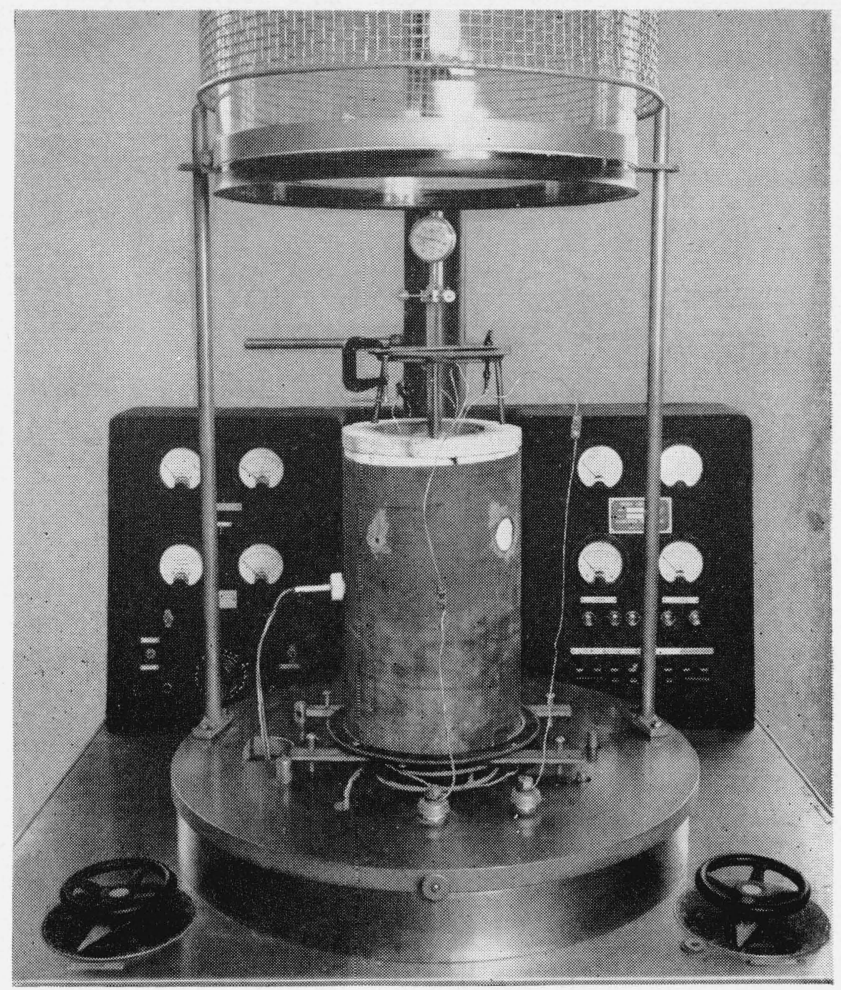

Figure 2. Equipment used for determining thermal expansion of graphite.

grade and orientation of graphite specimens was found to be \pm 0.02 percent (see table 3 ).

A test of the apparatus was made by measuring the expansion of a single crystal of periclase $(\mathrm{MgO})$ to $1,370^{\circ} \mathrm{C}$ in vacuum and comparing the results with a previous dilatometer measurement on the same specimen heated to $1,700^{\circ} \mathrm{C}$ in air (see footnote $6)$. The comparison is given in table 1 .

TABLE 1. Comparison of the linear thermal expansion data obtained on the same $\mathrm{MgO}$ specimen in vacuum and in air

\begin{tabular}{|c|c|c|}
\hline \multirow{2}{*}{$\begin{array}{l}\text { Room tem- } \\
\text { perature to- }\end{array}$} & \multicolumn{2}{|c|}{$\begin{array}{l}\text { Linear thermal expansion } \\
\text { in- }\end{array}$} \\
\hline & Vacuum a & Air b \\
\hline $\begin{array}{r}\circ C \\
100 \\
200 \\
300 \\
400 \\
500 \\
600 \\
700 \\
800 \\
900 \\
1,000 \\
1,100 \\
1,200 \\
1,300 \\
1,370\end{array}$ & $\begin{array}{c}\text { Percent } \\
0.09 \\
.20 \\
.32 \\
.47 \\
.61 \\
.75 \\
.89 \\
1.04 \\
1.19 \\
1.32 \\
1.47 \\
1.61 \\
1.77 \\
1.88\end{array}$ & $\begin{array}{c}\text { Percent } \\
0.06 \\
.16 \\
.30 \\
.43 \\
.58 \\
.71 \\
.87 \\
1.01 \\
1.17 \\
1.32 \\
1.48 \\
1.64 \\
1.81 \\
1.93\end{array}$ \\
\hline
\end{tabular}

a No loss in weight was found as a result of heating in a vacuum.

b Geller and Yavorsky (see footnote 6). No data on cooling were reported by these observers.

Another check of the apparatus was obtained by comparing the dilatometer measurements with those obtained by the interferometer method between 
room temperature and $400^{\circ} \mathrm{C}$. The agreement obtained with specimens of grade A graphite is given in table 2 .

\section{Results and Discussion}

The linear thermal expansions and contractions expressed in percentage for 100-deg intervals from room temperature to $1,370^{\circ} \mathrm{C}$, and the average coefficients of expansion and contraction per degree centigrade over 200-deg intervals, are given in table 3 for each of the three grades of graphite and for the three directions with respect to forming pressure (one parallel and two perpendicular).
Values are given for at least two specimens representing each grade and orientation with respect to the direction of forming. Also, tests were repeated twice for specimen $X_{1}$ of grade $A$ and once for specimen $A_{1}$ of grade $B$ to show the reproducibility. Moreover, specimens $\mathrm{X}_{1}$ and $\mathrm{X}_{2}$ of grade $\mathrm{A}$ were taken from the inside of the block (see fig. 1) to compare with specimens $A_{1}$ and $A_{2}$ of grade $A$ from the outside face of the block, both pairs of specimens cut parallel to the extrusion direction. The average of the linear thermal expansion values from table 3 are shown in figure 3. Average coefficients of expansion computed from the curves in figure 3 are given for intervals of 200-deg centigrade in table 4 .

TABLE 2. Comparison of expansions of grade A graphite determined by the interferometer and the dilatometer methods

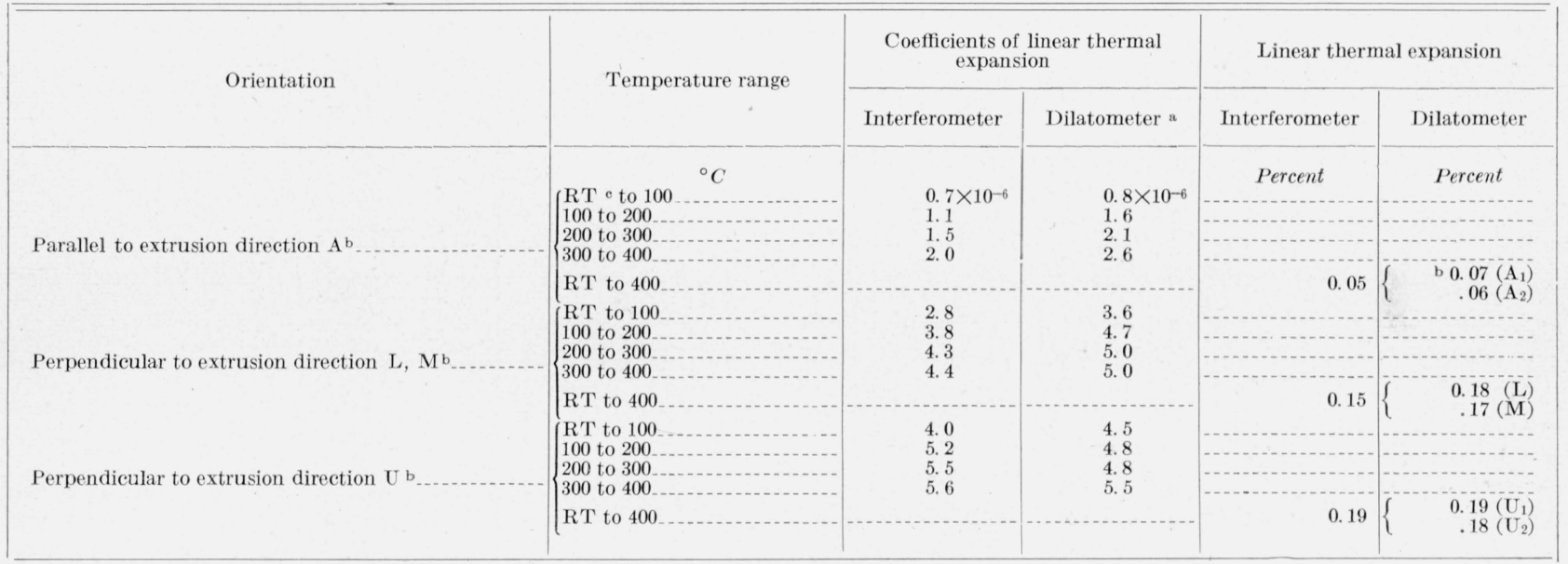

a Average of 2 companion specimens.

b See orientation diagram, fig. 1.

- $\mathrm{RT}=$ room temperature.

The differences in the expansions perpendicular and parallel to the direction of forming, for the three grades of graphite, are attributed to the different degree of preferred orientation, and to the marked anisotropy of the graphite crystal. The positions of the crystals depend on the method of forming. With the extruded graphites, the $\mathrm{C}$ axes of the hexagonal crystal plates tend to be alined perpendicular to the sides of the die, this tendency being a function of the size of the grains, the density of the mass, the extrusion pressure, the size and shape of the die, etc. In the case of the molded graphite, the crystal plates tend to be alined with the $\mathrm{C}$ axes parallel to the sides of the mold. Since the direction of greatest expansion of the graphite crystal is parallel to the $\mathrm{C}$ axis (i. e., perpendicular to the basal cleavage), the specimens cut parallel to the direction of molding pressure and perpendicular to the extrusion direction showed the greater expansion. As is generally the case with clay bodies, the crystals are preferentially oriented to a greater degree by extrusion than by molding. This accounts for the fact that in the case of graphites A and B the difference in expansion between specimens cut parallel and perpendicular to the extrusion direction is greater than the difference for comparable specimens of molded graphite C.
In the case of grade B graphite, the two pairs of specimens (U, T and $\mathrm{L}_{1}, \mathrm{~L}_{2}$ ), which were cut perpendicular to each other and to the direction of forming, differed significantly from each other in their linear thermal expansion. For comparable specimens of grades $\mathrm{A}$ and $\mathrm{C}$, this difference was not significant. The large and rectangular die opening used in extruding the grade B graphite may have allowed a different degree of orientation of crystals between die faces than the relatively small square opening used for extruding grade A. This same explanation may account for the uniformity of expansion values for specimens of grade A cut parallel to the extrusion direction, despite the fact that specimens $\mathrm{X}_{1}$ and $\mathrm{X}_{2}$ were cut from the center of the block. Note in table 3 the uniformity of the expansion values for various specimens of grade A graphite cut perpendicular and parallel to the extrusion direction for tests in which the temperature was measured in the same manner, that is, with the protected thermocouple or with the bare thermocouple.

The results of the determinations for indicating the reproducibility are given in table 5. Comparison shows that the values do not deviate materially. Note that in test 44 the temperature was maintained for at least 1 hour at each of 10 temperatures. This 
TABLE 3. Linear thermal expansion and contraction data of oriented specimens from three grades of graphite

\begin{tabular}{|c|c|c|c|c|c|c|c|c|c|c|c|c|c|c|c|c|}
\hline \multirow{2}{*}{ Orientation ${ }^{a}$} & \multirow{2}{*}{$\begin{array}{c}\text { Speei- } \\
\text { men }\end{array}$} & \multirow{2}{*}{$\begin{array}{l}\text { Test } \\
\text { No. }{ }^{b}\end{array}$} & \multicolumn{14}{|c|}{ Linear thermal expansion and contraction from room temperature to- } \\
\hline & & & $100^{\circ} \mathrm{C}$ & $200^{\circ} \mathrm{C}$ & $300^{\circ} \mathrm{C}$ & $400^{\circ} \mathrm{C}$ & $500^{\circ} \mathrm{C}$ & $600^{\circ} \mathrm{C}$ & $700^{\circ} \mathrm{C}$ & $800^{\circ} \mathrm{C}$ & $900^{\circ} \mathrm{C}$ & $1,000^{\circ} \mathrm{C}$ & $1,100^{\circ} \mathrm{C}$ & $1,200^{\circ} \mathrm{C}$ & $1,300^{\circ} \mathrm{C}$ & $1,370^{\circ} \mathrm{C}^{\mathrm{c}}$ \\
\hline \multicolumn{17}{|c|}{ Grade A (extruded) } \\
\hline $\begin{array}{c}\text { Perpendicular } \\
\text { Do }\end{array}$ & $\begin{array}{l}\mathrm{A}_{1} \\
\mathrm{~A}_{2} \\
\mathrm{X}_{1} \\
\mathrm{X}_{2} \\
\mathrm{~L} \\
\mathrm{M} \\
\mathrm{U}_{1} \\
\mathrm{U}_{2}\end{array}$ & $\left\{\begin{array}{r}20 \\
21 \\
18 \\
43 \\
.44 \\
19 \\
14 \\
17 \\
15 \\
16\end{array}\right.$ & $\begin{array}{c}\text { Percent } \\
0.01 \\
.00 \\
.01 \\
.00 \\
.00 \\
.00 \\
.03 \\
.02 \\
.03 \\
.04\end{array}$ & $\begin{array}{l}\text { Percent } \\
0.02 \\
.02 \\
.04 \\
.01 \\
.01 \\
.02 \\
.08 \\
.08 \\
.08\end{array}$ & $\begin{array}{l}\text { Percent } \\
0.04 \\
.04 \\
.06 \\
.03 \\
.03 \\
.04 \\
.13 \\
.12 \\
.13 \\
.13\end{array}$ & $\begin{array}{r}\text { Percent } \\
\text { d0.07(.05) } \\
.06(.04) \\
.09(.07) \\
.05(.00) \\
.05 \\
.07(.05) \\
.18(.14) \\
.17(.13) \\
.19(.17) \\
.18(.15)\end{array}$ & $\begin{array}{r}\text { Percent } \\
0.10(.07) \\
.09(.07) \\
.11(.10) \\
.07(.02) \\
.07 \\
.10(.07) \\
.24(.19) \\
.22(.19) \\
.24(.22) \\
.24(.20)\end{array}$ & $\begin{array}{r}\text { Percent } \\
0.13(.10) \\
.12 .10) \\
.14(.12) \\
.10(.04) \\
.09 \\
.13(.10) \\
.29(.24) \\
.28(.24) \\
.30(.28) \\
.29(.25)\end{array}$ & $\begin{array}{r}\text { Percent } \\
0.16(.13) \\
.15(.12) \\
.17(.15) \\
.13(.06) \\
.12(16(13) \\
.16(.129) \\
.34(.30) \\
.36(.33) \\
.34(.31)\end{array}$ & $\begin{array}{r}\text { Percent } \\
0.19(.16) \\
.18(.16) \\
.20(.18) \\
.16(.09) \\
.15 \\
.18(.16) \\
.40(.35) \\
.39(.35) \\
.42 .39) \\
.40(.36)\end{array}$ & $\begin{array}{r}\text { Percent } \\
0.22(.19) \\
.21 .19) \\
.23(.21) \\
.19(.12) \\
.18(.22(19) \\
.45(.41) \\
.45(.41) \\
.48(.45) \\
.46(.42)\end{array}$ & $\begin{array}{r}\text { Percent } \\
0.25(.22) \\
.25(.22) \\
.27(.24) \\
.22(.15) \\
.21 \\
.25(.22) \\
.51(.47) \\
.51(.48) \\
.54(.51) \\
.51(.48)\end{array}$ & $\begin{array}{r}\text { Percent } \\
0.28(.26) \\
.28(.26) \\
.30(.28) \\
.25(.19) \\
.24(.19) \\
.28(.26) \\
.57(.53) \\
.57(.54) \\
.61(.57) \\
.58(.54)\end{array}$ & $\begin{array}{r}\text { Percent } \\
0.32(.30) \\
.32(.30) \\
.34(.32) \\
.28(.24) \\
.27(.29) \\
.31(.29) \\
.63(.61) \\
.64(.61) \\
.67(.65) \\
.64(.61)\end{array}$ & $\begin{array}{r}\text { Percent } \\
0.36(.34) \\
.37 .34) \\
.37(.36) \\
.32(.29) \\
.31 \\
.35(.33) \\
.70(.60) \\
.70(.60) \\
.74(.72) \\
.70(.68)\end{array}$ & $\begin{array}{r}\text { Percent } \\
0.38(.38) \\
.40(.39) \\
.40(40) \\
.35(.32) \\
.33 \\
.38(.37) \\
.74(.74) \\
.75 .74) \\
.79(.78) \\
.74(.74)\end{array}$ \\
\hline \multicolumn{17}{|c|}{ Grade B (extruded) } \\
\hline $\begin{array}{l}\text { Parallel } \\
\text { Perpendicular } \\
\text { Do }\end{array}$ & $\left\{\begin{array}{l}\mathrm{A}_{1} \\
\mathrm{~A}_{2} \\
\mathrm{~L}_{1} \\
\mathrm{~L}_{2} \\
\mathrm{U} \\
\mathrm{T}\end{array}\right.$ & $\left\{\begin{array}{l}28 \\
40 \\
33 \\
34 \\
35 \\
36 \\
37\end{array}\right.$ & $\begin{array}{r}0.01 \\
.01 \\
.01 \\
.02 \\
.02 \\
.03 \\
.03\end{array}$ & $\begin{array}{l}0.03 \\
.03 \\
.03 \\
.06 \\
.06 \\
.08 \\
.07\end{array}$ & $\begin{array}{l}0.05 \\
.05 \\
.06 \\
.09 \\
.10 \\
.13 \\
.12\end{array}$ & $\begin{array}{c}0.07(.02) \\
.07 \\
.08(.02) \\
.13(.06) \\
.14(.07) \\
.17(.07) \\
.16(.09)\end{array}$ & $\begin{array}{l}0.09(.04) \\
.10(.00) \\
.11(.04) \\
.17(.10) \\
.18(.10) \\
.21(.31) \\
.21(.13)\end{array}$ & $\begin{array}{l}0.11(.06) \\
.12(.02) \\
.14(.07) \\
.21(.14) \\
.22(.14) \\
.26(16) \\
.25(.17)\end{array}$ & $\begin{array}{l}0.14(.09) \\
.15(.05) \\
.16(.10) \\
.25(.18) \\
.26(.18) \\
.31(.20) \\
.30(.21)\end{array}$ & $\begin{array}{l}0.16(.11) \\
.17(.07) \\
.20(.12) \\
.29(.22) \\
.31(.22) \\
.36(.26) \\
.35(.26)\end{array}$ & $\begin{array}{l}0.19(.14) \\
.20(.10) \\
.22(.16) \\
.34(.26) \\
.36(.28) \\
.41(.32) \\
.40(.32)\end{array}$ & $\begin{array}{r}0.22(.17) \\
.23(.15) \\
.26(.20) \\
.38(.31) \\
.41(.33) \\
.46(.38) \\
.45(.38)\end{array}$ & $\begin{array}{r}0.25(.20) \\
.26(.16) \\
.29(.24) \\
.43(.37) \\
.46(.39) \\
.52(.45) \\
.51(.44)\end{array}$ & $\begin{array}{l}0.28(.24) \\
.29(.21) \\
.32(.28) \\
.48(.43) \\
.51(.46) \\
.58(.52) \\
.57(.52)\end{array}$ & $\begin{array}{r}0.32(.29) \\
.32(.26) \\
.37(.34) \\
.53(.50) \\
.56(.54) \\
.64(.60) \\
.63(.60)\end{array}$ & $\begin{array}{l}0.34(.33) \\
.34(.30) \\
.40(.38) \\
.57(.55) \\
.61(.60) \\
.68(.66) \\
.68(.66)\end{array}$ \\
\hline \multicolumn{17}{|c|}{ Grade C (molded) } \\
\hline $\begin{array}{l}\text { Parallel } \\
\text { Perpendicular } \\
\text { Do }\end{array}$ & $\left\{\begin{array}{l}\mathrm{A}_{1} \\
\mathrm{~A}_{2} \\
\mathrm{~B}_{1} \\
\mathrm{~B}_{2} \\
\mathrm{~T}_{1} \\
\mathrm{~T}_{2} \\
\mathrm{~L}_{1} \\
\mathrm{~L}_{2}\end{array}\right.$ & $\begin{array}{l}22 \\
23 \\
29 \\
32 \\
24 \\
25 \\
26 \\
27\end{array}$ & $\begin{array}{l}0.03 \\
.03 \\
.04 \\
.03 \\
.02 \\
.03 \\
.02 \\
.02\end{array}$ & $\begin{array}{r}0.08 \\
.07 \\
.08 \\
.08 \\
.05 \\
.06 \\
.05 \\
.05\end{array}$ & $\begin{array}{l}0.14 \\
.11 \\
.12 \\
.12 \\
.09 \\
.09 \\
.08 \\
.09\end{array}$ & $\begin{array}{l}0.19(.16) \\
.16(.07) \\
.17(.12) \\
.17(.12) \\
.12(.08) \\
.12(.06) \\
.11(.06) \\
.12(.08)\end{array}$ & $\begin{array}{l}0.24(.22) \\
.20(.12) \\
.22(.16) \\
.22(17) \\
.16(.11) \\
.16(.10) \\
.15(.09) \\
.15(.13)\end{array}$ & $\begin{array}{l}0.30(.27) \\
.24(.16) \\
.26(.20) \\
.27(.21) \\
.20(.14) \\
.19(.13) \\
.18(.12) \\
.19(.16)\end{array}$ & $\begin{array}{l}0.35(.32) \\
.29(.21) \\
.31(.25) \\
.32(.26) \\
.24(.18) \\
.23(.17) \\
.22(.16) \\
.23(.19)\end{array}$ & $\begin{array}{l}0.41(.38) \\
.34(.26) \\
.36(.33) \\
.38(.32) \\
.28(.22) \\
.27(.21) \\
.26(.20) \\
.26(.22)\end{array}$ & $\begin{array}{r}0.47(.44) \\
.39(.31) \\
.41(.36) \\
.43(37) \\
.33(.25) \\
.31(.25) \\
.30(.24) \\
.30(.25)\end{array}$ & $\begin{array}{r}0.53(.50) \\
.44(.36) \\
.47(.40) \\
.48(.44) \\
.37(.30) \\
.35(.29) \\
.34(.29) \\
.35(.29)\end{array}$ & $\begin{array}{r}0.59(.56) \\
.49(.42) \\
.52(.47) \\
.54(.50) \\
.42(.34) \\
.39(.34) \\
.39(.33) \\
.39(.34)\end{array}$ & $\begin{array}{r}0.65(.62) \\
.54(.48) \\
.58(.53) \\
.60(.56) \\
.46(.40) \\
.44(.39) \\
.44(.38) \\
.44(.39)\end{array}$ & $\begin{array}{c}0.72(.70) \\
.59(.55) \\
.63(.61) \\
.65(.63) \\
.50(.46) \\
.49(.45) \\
.48(.44) \\
.48(.44)\end{array}$ & $\begin{array}{r}0.76(.76) \\
f .60(.60) \\
.68(.66) \\
.70(.68) \\
f .54(.51) \\
f .52(.50) \\
f .52(.50) \\
f .52(.50)\end{array}$ \\
\hline
\end{tabular}


TABLE 3. Linear thermal expansion and contraction data of oriented specimens from three grades of graphite-Continued

\begin{tabular}{|c|c|c|c|c|c|c|c|c|c|}
\hline \multirow{2}{*}{ Orientation ${ }^{a}$} & \multirow{2}{*}{$\begin{array}{l}\text { Speci- } \\
\text { men }\end{array}$} & \multirow{2}{*}{$\begin{array}{l}\text { Test } \\
\text { No. }{ }^{b}\end{array}$} & \multicolumn{7}{|c|}{ Coefficients of linear thermal expansion- } \\
\hline & & & $\begin{array}{l}\text { Room tempera. } \\
\text { ture to } 200^{\circ} \mathrm{C}\end{array}$ & $200^{\circ}$ to $400^{\circ} \mathrm{C}$ & $400^{\circ}$ to $600^{\circ} \mathrm{C}$ & $600^{\circ}$ to $800^{\circ} \mathrm{C}$ & $800^{\circ}$ to $1,000^{\circ} \mathrm{C}$ & $1,000^{\circ}$ to $1,200^{\circ} \mathrm{C}$ & $1,200^{\circ}$ to $1,370^{\circ} \mathrm{C} c$ \\
\hline \multicolumn{10}{|c|}{ Grade A (extruded) } \\
\hline $\begin{array}{l}\text { Parallel } \\
\text { Perpendicular } \\
\quad \text { Do }\end{array}$ & $\begin{array}{l}\mathrm{A}_{1} \\
\mathrm{~A}_{2} \\
\mathrm{X}_{1} \\
\mathrm{X}_{2} \\
\mathrm{~L} \\
\mathrm{M} \\
\mathrm{U}_{1} \\
\mathrm{U}_{2}\end{array}$ & $\left\{\begin{array}{r}20 \\
21 \\
18 \\
43 \\
44 \\
19 \\
14 \\
17 \\
15 \\
16\end{array}\right.$ & $\begin{array}{l}1.3 \times 10^{-6} \\
1.1 \\
2.1 \\
0.8 \\
0.8 \\
1.2 \\
4.5 \\
4.0 \\
4.7 \\
4.7\end{array}$ & $\begin{array}{l}2.4 \times 10^{-6} \\
2.3 \\
2.5 \\
1.8 \\
1.7 \\
2.6 \\
5.1 \\
5.1 \\
5.3 \\
5.0\end{array}$ & $\begin{array}{l}2.8(2.8) \times 10^{-6} \\
2.8(2.8) \\
2.9(2.7) \\
2.5(2.0) \\
2.3 \\
2.8(2.6) \\
5.4(5.1) \\
5.5(5.3) \\
5.6(5.3) \\
5.3(5.2)\end{array}$ & $\begin{array}{l}\text { 2. } 9(3.0) \times 10^{-6} \\
\text { 2. } 9(3.0) \\
3.0(2.8) \\
2.9(2.4) \\
2.8 \\
2.9(3.0) \\
5.5(5.5) \\
5.6(5.5) \\
5.9(5.4) \\
5.6(5.4)\end{array}$ & $\begin{array}{l}\text { 3. } 2(3.7) \times 10^{-6} \\
\text { 3. } 4(3.2) \\
3.1(3.2) \\
3.0(3.1) \\
3.0 \\
3.1(3.1) \\
5.7(5.9) \\
6.0(6.2) \\
6.1(6.3) \\
5.8(6.0)\end{array}$ & $\begin{array}{l}\text { 3. } 5(3.6) \times 10^{-6} \\
3.7(3.7) \\
3.6(3.8) \\
3.2(4.4) \\
3.2 \\
3.2(3.6) \\
6.1(6.8) \\
6.0(6.8) \\
6.5(6.9) \\
6.0(6.5)\end{array}$ & $\begin{array}{l}\text { 3. } 7(4.5) \times 10^{-6} \\
4.5(5.5) \\
3.8(4.4) \\
3.7(4.8) \\
3.4 \\
3.8(4.4) \\
6.4(7.8) \\
6.6(7.7) \\
6.8(7.7) \\
6.3(7.5)\end{array}$ \\
\hline \multicolumn{10}{|c|}{ Grade B (extruded) } \\
\hline $\begin{array}{l}\text { Parallel. } \\
\text { Perpendicular. } \\
\text { Do }\end{array}$ & $\left\{\begin{array}{l}\mathrm{A}_{1} \\
\mathrm{~A}_{2} \\
\mathrm{~L}_{1} \\
\mathrm{~L}_{2} \\
\mathrm{U} \\
\mathrm{T}\end{array}\right.$ & $\left\{\begin{array}{l}28 \\
40 \\
33 \\
34 \\
35 \\
36 \\
37\end{array}\right.$ & $\begin{array}{l}1.8 \\
1.7 \\
2.1 \\
3.4 \\
3.5 \\
4.5 \\
4.1\end{array}$ & $\begin{array}{l}2.0 \\
2.1 \\
2.4 \\
3.6 \\
3.7 \\
4.5 \\
4.5\end{array}$ & $\begin{array}{l}2.1(2.0) \\
2.4(2.1) \\
2.6(2.4) \\
4.0(3.8) \\
4.2(3.3) \\
4.5(4.3) \\
4.6(4.0)\end{array}$ & $\begin{array}{l}2.5(2.4) \\
2.6(2.4) \\
2.9(2.7) \\
4.2(4.1) \\
4.5(4.2) \\
4.9(5.3) \\
4.9(4.7)\end{array}$ & $\begin{array}{l}2.8(2.9) \\
2.8(2.9) \\
3.1(3.5) \\
4.6(4.7) \\
4.8(5.2) \\
5.3(6.1) \\
5.2(5.7)\end{array}$ & $\begin{array}{l}3.2(3.5) \\
2.9(3.8) \\
3.3(4.3) \\
4.8(5.8) \\
5.1(6.4) \\
5.7(7.0) \\
5.6(7.1)\end{array}$ & $\begin{array}{l}3.4(5.1) \\
3.0(5.7) \\
4.1(5.7) \\
5.3(7.1) \\
5.9(7.9) \\
6.0(8.2) \\
6.4(8.0)\end{array}$ \\
\hline \multicolumn{10}{|c|}{ Grade $\mathrm{C}$ (molded) } \\
\hline $\begin{array}{l}\text { Parallel } \\
\text { Perpendicular } \\
\text { Do }\end{array}$ & $\begin{array}{l}\left\{\begin{array}{l}\mathrm{A}_{1} \\
\mathrm{~A}_{2} \\
\mathrm{~B}_{1} \\
\mathrm{~B}_{2} \\
\mathrm{~T}_{1} \\
\mathrm{~T}_{2} \\
\mathrm{~L}_{1} \\
\mathrm{~L}_{2}\end{array}\right.\end{array}$ & $\begin{array}{l}22 \\
23 \\
29 \\
32 \\
24 \\
25 \\
26 \\
27\end{array}$ & $\begin{array}{l}5.0 \\
4.0 \\
4.4 \\
4.6 \\
2.9 \\
3.2 \\
2.8 \\
3.1\end{array}$ & $\begin{array}{l}5.2 \\
4.3 \\
4.5 \\
4.6 \\
3.6 \\
3.2 \\
3.2 \\
3.4\end{array}$ & $\begin{array}{l}5.3(5.3) \\
4.3(4.3) \\
4.7(4.3) \\
5.0(4.6) \\
3.8(3.0) \\
3.6(3.5) \\
3.5(3.0) \\
3.5(3.8)\end{array}$ & $\begin{array}{l}5.8(5.6) \\
4.9(4.9) \\
4.9(4.7) \\
5.4(5.1) \\
4.1(3.5) \\
3.8(3.8) \\
3.9(3.9) \\
3.7(2.9)\end{array}$ & $\begin{array}{l}\text { 6. } 0(5.9) \\
5.0(5.1) \\
5.3(5.3) \\
5.3(5.9) \\
4.4(4.0) \\
4.1(4.1) \\
4.3(4.2) \\
4.2(3.6)\end{array}$ & $\begin{array}{l}\text { 6.1(6.3) } \\
5.0(5.9) \\
5.4(6.3) \\
5.6(6.3) \\
4.5(5.0) \\
4.4(4.9) \\
4.5(4.9) \\
4.4(4.9)\end{array}$ & $\begin{array}{r}6.5(7.9) \\
\text { f } 5.3(7.3) \\
5.9(7.8) \\
5.9(7.0) \\
\text { f.5(6.7) } \\
\text { f } 4.8(6.6) \\
\text { f } 4.8(6.6) \\
\text { f } 5.1(6.3)\end{array}$ \\
\hline
\end{tabular}

a Relative positions of the specimens with respect to each other and with respect to the direction of extrusion or molding pressure can be seen in fig.

hromel-alumel thermocouples were used. Tests 1 ple was used in tests 1 through 22 , after which

- Held at $1,370^{\circ}$ for $45 \mathrm{~min}$. before cooling.

- Held for at least 1 hour at each of 10 temperatures between room temperature and $1,370^{\circ} \mathrm{C}$, Other missing test numbers were either faulty tests or tests of other materials.
Otherials

TABLE 4. Average coefficients of linear thermal expansion for three graphites

\begin{tabular}{|c|c|c|c|c|c|c|c|}
\hline \multirow[b]{2}{*}{ Grade } & \multirow[b]{2}{*}{ Orientation a } & \multicolumn{6}{|c|}{ A verage coefficients of expansion from- } \\
\hline & & $\begin{array}{l}\text { Room } \\
\text { tempera- } \\
\text { ture to } \\
200^{\circ} \mathrm{C}\end{array}$ & $\begin{array}{l}200^{\circ} \text { to } \\
400^{\circ} \mathrm{C}\end{array}$ & $\begin{array}{l}400^{\circ} \text { to } \\
600^{\circ} \mathrm{C}\end{array}$ & $\begin{array}{l}600^{\circ} \text { to } \\
800^{\circ} \mathrm{C}\end{array}$ & $\begin{array}{r}800^{\circ} \text { to } \\
1,000^{\circ} \mathrm{C}\end{array}$ & $\begin{array}{l}1,000^{\circ} \text { to } \\
1,200^{\circ}\end{array}$ \\
\hline $\begin{array}{l}\text { A (extruded) } \ldots \\
\text { B (extruded) } \\
\text { C (molded) }\end{array}$ & 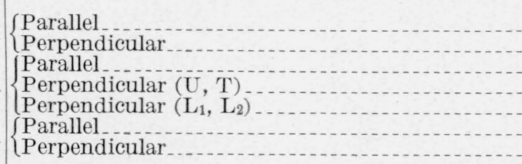 & $\begin{array}{l}2.0 \times 10^{-6} \\
4.9 \\
2.0 \\
4.4 \\
3.6 \\
4.4 \\
3.2\end{array}$ & $\begin{array}{l}2.6 \times 10^{-6} \\
\text { 5. } \\
2.4 \\
4.5 \\
\text { 4. } 0 \\
\text { 5. } 0 \\
\text { 3. } 4\end{array}$ & $\begin{array}{l}\text { 3. } 0 \times 10^{-6} \\
5.5 \\
2.5 \\
5.0 \\
4.2 \\
5.0 \\
3.7\end{array}$ & $\begin{array}{l}\text { 3. } 0 \times 10^{-6} \\
5.7 \\
\text { 3. } 0 \\
5.0 \\
\text { 4. } 5 \\
5.2 \\
4.0\end{array}$ & $\begin{array}{l}\text { 3. } 4 \times 10^{-6} \\
6.0 \\
3.1 \\
\text { 5. } 5 \\
\text { 4. } 9 \\
5.4 \\
4.2\end{array}$ & $\begin{array}{l}\text { 3. } 5 \times 10^{-6} \\
6.5 \\
3.5 \\
6.0 \\
5.1 \\
5.9 \\
4.5\end{array}$ \\
\hline
\end{tabular}

a With respect to direction of extrusion or molding pressure, 

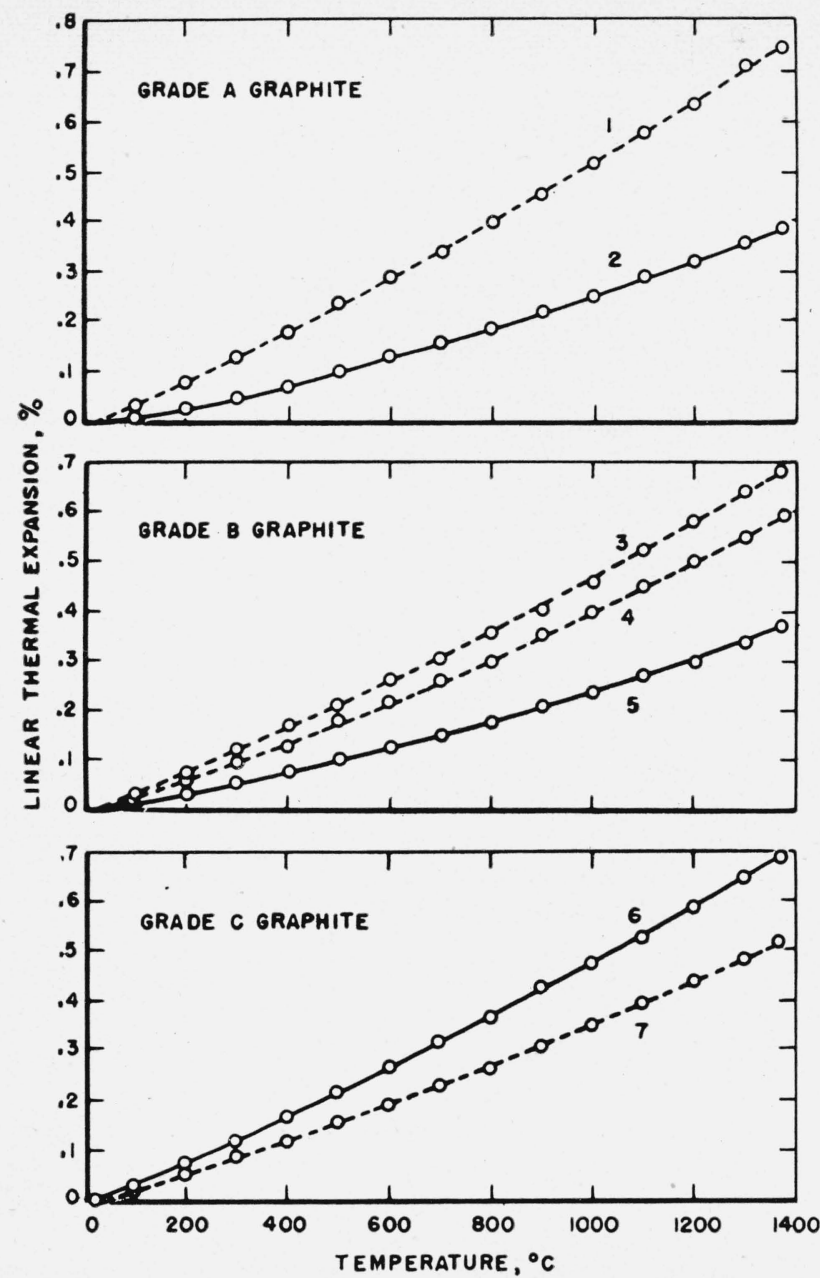

Figure 3. Average linear thermal expansion of three graphites.

Grade A graphite: 1, average of four specimens perpendicular to extrusion direction; 2, average of four specimens parallel to extrusion direction. Grade B graphite: 3, average of two specimens, $U$ and $T$, perpendicular to extrusion direction; 4 , average of two specimens, $L_{1}$ and $L_{2}$, perpendicular to extrusion graphite: 6, average of four specimens parallel to molding pressure; 7 , average of four specimens perpendicular to molding pressure.

was done to evaluate the lag in temperature measurements made with the bare chromel-alumel thermocouple. The expansion measurements show that above $600^{\circ} \mathrm{C}$ the values during the regular test (43) were slightly larger in every case, indicating a temperature measurement lag. However, the difference does not materially affect the expansion values.

No attempt was made to compare the thermal expansion determinations of the three graphites investigated in this work with determinations of other graphites because of the wide variation of values found in the literature. The variation is attributed to the anisotropic characteristic of the crystal and the structural nature of the mass. The structure of a graphite body is unlike that of a metal or a porcelain body. The flat graphite crystals do not form impermeable solids, but rather a low density porous body. The many voids decrease the total thermal expansion considerably. The total effect would depend on the grain size and pore distribution.

The work of Nelson and Riley (see footnote 2) and Pierry (see footnote 3) indicates the degree of anisotropy of the graphite crystal. Most of the thermal expansion of the crystal is due to the expansion in the "C" direction. Along the " $\mathrm{C}$ " axis, the former observers (see footnote 2 ) found that the coefficient of expansion was about $29 \times 10^{-6}$, and along the " $\mathrm{A}$ " axis only $0.9 \times 10^{-6}$ between $600^{\circ}$ and $800^{\circ} \mathrm{C}$.

TABLE 5. Linear thermal expansion data obtained from repeat tests ${ }^{\text {a }}$ of two grades of graphite

\begin{tabular}{|c|c|c|c|c|}
\hline \multirow{2}{*}{ Temperature range } & \multicolumn{2}{|c|}{ Grade $\mathrm{A}$ specimen $\mathrm{X}_{1}{ }^{\mathrm{b}}$} & \multicolumn{2}{|c|}{ Grade $B$ specimen $A_{1}$} \\
\hline & Test 43 & Test 44 & Test 28 & Test 40 \\
\hline \multicolumn{5}{|c|}{ Linear thermal expansion } \\
\hline $\begin{array}{l}{ }^{\circ} C \\
\text { RT e to } 100 \\
\text { RT to } 200 \\
\text { RT to } 300 \\
\text { RT to } 400 \\
\text { RT to } 500 \\
\text { RT to } 600 \\
\text { RT to } 700 \\
\text { RT to } 800 \\
\text { RT to } 900 \\
\text { RT to } 1,000 \\
\text { RT to } 1,100 \\
\text { RT to } 1,200 \\
\text { RT to } 1,300 \\
\text { RT to } 1,370\end{array}$ & $\begin{array}{c}\text { Percent } \\
0.00 \\
.01 \\
.03 \\
.05 \\
.07 \\
.10 \\
.13 \\
.16 \\
.19 \\
.22 \\
.25 \\
.28 \\
.32 \\
.35\end{array}$ & $\begin{array}{c}\text { Percent } \\
0.00 \\
.01 \\
.03 \\
.05 \\
.07 \\
.09 \\
.12 \\
.15 \\
.18 \\
.21 \\
.24 \\
.27 \\
.31 \\
.33\end{array}$ & $\begin{array}{c}\text { Percent } \\
0.01 \\
.03 \\
.05 \\
.07 \\
.09 \\
.11 \\
.14 \\
.16 \\
.19 \\
.22 \\
.25 \\
.28 \\
.32 \\
.34\end{array}$ & $\begin{array}{c}\text { Percent } \\
0.01 \\
.03 \\
.05 \\
.07 \\
.10 \\
.12 \\
.15 \\
.17 \\
.20 \\
.23 \\
.26 \\
.29 \\
.32 \\
.34\end{array}$ \\
\hline \multicolumn{5}{|c|}{ Average coefficients of linear thermal expansion } \\
\hline $\begin{array}{l}\text { RT to } 200 \\
200 \text { to } 400 \\
400 \text { to } 600 \\
600 \text { to } 800 \\
800 \text { to } 1,000 \\
1,000 \text { to } 1,200 \\
1,200 \text { to } 1,370\end{array}$ & $\begin{array}{l}0.8 \times 10^{-6} \\
1.8 \\
2.5 \\
2.9 \\
3.0 \\
3.2 \\
3.7\end{array}$ & $\begin{array}{l}0.8 \times 10^{-6} \\
1.7 \\
2.3 \\
2.8 \\
3.0 \\
3.2 \\
3.4\end{array}$ & $\begin{array}{l}1.8 \times 10^{-6} \\
2.0 \\
2.1 \\
2.5 \\
2.8 \\
3.2 \\
3.4\end{array}$ & $\begin{array}{l}1.7 \times 10^{-6} \\
2.1 \\
2.4 \\
2.6 \\
2.8 \\
2.9 \\
3.0\end{array}$ \\
\hline
\end{tabular}

a Tests 43 and 44 are first and second heatings, and tests 28 and 40 are second and third heatings.

b Test 18 was not included because of the expected difference between expansion values due to the different method of measuring temperature.

- RT=room temperature.

\section{Summary}

1. The linear thermal expansion of specimens of three grades of graphite, cut in three directions with respect to the direction of extrusion or of molding pressure, was determined at various temperatures between $20^{\circ}$ and $1,370^{\circ} \mathrm{C}$ in vacuum.

2. Specimens cut perpendicular to the extrusion direction or parallel to the direction of molding had greater expansions than specimens cut parallel to the extrusion direction or perpendicular to the molding pressure.

3. It was found that chromel-alumel thermocouples could be used successfully in vacuum at temperatures well above those at which they fail in air.

Washington, September 13, 1950. 